\title{
Ventilation for the nation:
}

\section{Fresh air, sunshine, and the warfare on germs in China's national quest for hygienic modernity, 1849-1949}

\author{
Rune Svarverud \\ Department of Culture Studies and Oriental Languages \\ University of Oslo
}

\section{Introduction}

We second-year students walked out of the school gate into a different world together with some of our teachers. Our faces were covered in smiles. I realized that this was a manifestation of the frustrations of city life, longing for the mental comfort of nature. It was as if I could no longer smell the foul air, and no longer hear the noise of the city.... The autumn leaves intoxicated us. I saw myself and my fellow students raising our firm fists, faces cracking up in happy smiles, two pitch-black, shiny eyes, gazing straight ahead. ${ }^{1}$

In her 1936 article 'Taking a deep breath of fresh air', Zhu Mulan, an urban, second-year, Chinese middle-school student, described how fresh air, the mental comfort provided by nature, and country life in general appeared as her best hope for a happy future. By the 1930s, urban air in China had become increasingly polluted by industry; city streets were filled with vehicles, and pavements were crowded with pedestrians. In the 1930s, urban citizens and young students like Zhu described the yearning for a return to unsullied life and clean air, often coupled with aspirations for a strong Chinese nation. A longing for fresh air, the mental comfort of nature, and rural life distant from the frustrations of the city indicate an attitude towards individual and national aspirations for the future, health, and happiness that would have been quite unheard of in China a few decades earlier. Until the middle of the nineteenth century, prescriptions for the health of the individual were provided through traditional Chinese schemes for 'guarding life' (weisheng 衛生), and cures of diseases were consigned

\footnotetext{
${ }^{1}$ Zhu Mulan 朱慕蘭, ‘Shenshen de huxi le yikou xinxian kongqi’ 深深地呼吸了一 $\square$ 新鮮空氣 [Taking a Deep Breath of Fresh Air], Langhua 浪花 2 (1936): 34-5.
} 
through traditional medical and pharmacological practices. ${ }^{2}$ This changed radically with the introduction of medical knowledge from the West starting in the $1850 \mathrm{~s}^{3}{ }^{3}$ Scientific knowledge had begun seeping into China in the 1840 s, slowly at first to pockets of intellectuals and professionals via translated texts, and later, via Japan, more rapidly as popular science became accessible through trendy magazines and public education. ${ }^{4}$ Chinese approaches to nature, the environment, individual and public health, and national prosperity changed fundamentally from the 1840s to the 1940s under the influence of this foreign knowledge.

Following the initial introduction, in 1849, of modern scientific ideas about the composition and quality of air, ${ }^{5}$ an awareness among the intellectual elite of the relationship between air quality and health emerged in China. In spite of gradually increasing air pollution from industry in some urban areas in China in the $1920 \mathrm{~s}$ and $30 \mathrm{~s},{ }^{6}$ the most health threatening and polluted air was commonly perceived to be indoor, and not outdoor, air by the Chinese public between 1849 and the CCP takeover in China in 1949. Indoor human activity was seen as the source of air pollution and foul air by scientists and the general public, and not industrial production and factories in the outdoor environment. Contrary to belief in China today, fresh air was to be sought outdoors, even in urban China, and healthy indoor air was obtained only by ventilating homes, rooms, and buildings by letting out the vitiated indoor air and taking in fresh air from the surrounding environment.

This article will engage with how Chinese approaches to fresh air, sunshine, dust, germs, and ventilation were transformed as interpretations of health, hygiene, and national prosperity shifted during this period. The article will argue that vitiated air in China was initially conceived as a threat to individual health and wellbeing, while later fresh air became a central element in the discourse on public hygiene and on strategies for building a strong

\footnotetext{
${ }^{2}$ Ruth Rogaski, Hygienic Modernity: Meanings of Health and Disease in Treaty-Port China (Berkeley, Los Angeles, London: University of California Press, 2004), pp. 22-47.

${ }^{3}$ Bridie Andrews, The Making of Modern Chinese Medicine, 1850-1960 (Honolulu: University of Hawai'i Press, 2014); Bridie Andrews and Mary Brown Bullock (eds.), Medical Transitions in Twentieth-Century China (Bloomington and Indianapolis: Indiana University Press, 2014); Sean Hsiang-Lin Lei, Neither Donkey nor Horse: Medicine in the Struggle over China's Modernity (Chicago and London: The University of Chicago Press, 2014).

${ }^{4}$ Benjamin A. Elman, On Their Own Terms: Science in China, 1550-1900 (Cambridge, MA and London: Harvard University Press, 2005); Peter Zarrow, Educating China: Knowledge, Society, and Textbooks in a Modernizing World, 1902-1937 (Cambridge: Cambridge University Press, 2015).

${ }^{5}$ Rune Svarverud, 'The Terminological Battle for “Air” in Modern China', Wakumon 或問 26 (2014): 23-44;

Rune Svarverud, "Genealogy of Chinese Perceptions of "Polluted Air": Conceptual Change and the Terminological Landscape of Air Pollution in Modern China', Journal of the History of Ideas in East Asia forthcoming (2018).

${ }^{6}$ Wang Yangzong 王楊宗, ‘Jindai gongye de jianli yu huanjing wenti’ 近代工業的建立與環境問題 [The Establishment of Modern Industry and Environmental Problems], in Luo Guihuan 羅桂環, Wang Yaoxian 王耀 先, Yang Chaofei 楊朝飛, and Tang Xiren 唐錫仁 (eds.), Zhongguo huanjing baohu shigao 中國環境保護史稿 [Historical Essays on Environmental Protection in China] (Beijing: Zhongguo huanjing kexue chubanshe, 1995), pp. 301-30.
} 
and healthy Chinese nation. Ventilation of homes became one of the predominant scientific and technical keys to a strong nation in this discourse in the 1920s and 30s, promoted primarily to the young generation of Chinese citizens through modern public education and edifying articles in children's magazines.

Notionally, this is a story of how science and technology constituted essential parts of the transmitted knowledge from West to East historically and how this knowledge took on new and indigenous forms in its Chinese context. The scientific discourse on vitiated indoor air and health commenced in the West, so that is where our inquiries begin. We will, in what follows, mainly use the United Kingdom as a reference point due to it being the source of early Chinese ideas about air quality and hygiene and health and the cachet that London had in the Chinese discourse on air pollution beginning in the $1870 \mathrm{~s}^{7}$

\section{The European sources of inspiration}

Chinese strategies to ventilate for a strong nation were inspired by European, in particular British, ideas about fresh air and the threat of the putrid and miasmal. In the fifth and fourth centuries BC, Hippocrates and his disciples formulated ideas about how air influenced human health, mentality, language, and spirits. Towards the end of the ancien régime, these ideas were developed into a sophisticated epidemiology, associating human health with various forms of air(s), smells, odours, vapours, and miasmas. The air of any given location was potentially threatening to human health because of emanations from the earth, 'perspirations' of decaying vegetable and animal substances, and, not least, contagious miasmas from decomposing bodies. Air could enter the body through the skin, pulmonary membranes, pores, or by digestion. Direct contact with stagnant air was hence to be prevented, or reduced to a minimum. Concern with miasmic influence on human health was of particular concern to British colonials who travelled to and lived for extended periods of time in warm, humid tropical areas. ${ }^{8}$ During the eighteenth century, scientists, chemists, doctors, and sanitarians worked to eradicate filth and seal off stagnant air from the human environment through draining, ventilation, plastering, and painting. Whenever they threatened to affect humans, air and dirt were to be kept in circulation to purify air and control miasmas, and ventilation ensured this circulation. Antoine Lavoisier's (1743-1794) scientific discoveries regarding the composition of air and the identification of breathing with combustion in the 1780s, significantly changing pneumatic chemistry; it was discovered that circulation in itself could

\footnotetext{
${ }^{7}$ Hongtao Li and Rune Svarverud, 'When London Hit the Headlines: Historical Analogy and the Chinese Media Discourse on Air Pollution'. The China Quarterly, 2017, https://doi.org/10.1017/S0305741017001400.

${ }^{8}$ Mark Harrison, Medicine in an Age of Commerce and Empire: Britain and its Tropical Colonies, 1660-1830 (Oxford: Oxford University Press, 2010), pp. 64-88.
} 
not enhance air quality. Henceforth, healthy air free from miasmas and other illness inducing substances was to be obtained by exchanging the air from inhabited areas with outdoor air. Concern over indoor air quality also entailed attention to breathing and what was frequently referred to as 'the family atmosphere', the 'miasmic intercourse' in the domestic space that could be deadly. Specific hygiene precautions, such as providing more space for each individual, were required to curb the negative effects of contamination caused by miasmic exhalations in the domestic space. As a result, sanitary reformers of the nineteenth century were concerned with domestic proximity to pure and fresh air and the means of controlling air flow. ${ }^{9}$

These perceptions of miasmic influence on health and the human body were augmented by quests for public strategies to counter new sources of foul air in the wake of industrialization and urbanization. In nineteenth-century British cities, air pollution caused by industry and home fires was increasingly causing health problems, which led to public debates on its causes and consequences, the measures needed to alleviate it, and its abatement. ${ }^{10}$ City streets smelling of putrefying matter caused by high population density too were of concern. Sanitary and engineering projects in Britain in the latter half of the nineteenth century were initiated to improve the sewage systems, remove refuse from the streets, and open up narrow streets and enclosed courtyards to circulate fresh air in urban spaces.

The same principles applied to 'cleaning up' indoor air, where stagnant air, depletion of oxygen, and the accumulation of carbonic acid gas, together with re-breathed air from human respiration were seen to be the causes of many diseases. These views on foul indoor air led to a desire for ventilation of indoor spaces which we will discuss in more detail below. Notions that both indoor and outdoor fresh air, free from unpleasant odours, dust and invisible health-threatening miasmas and gases, were needed for health and resistance to illness flourished even after germ theories replaced miasmic theories as the accepted medical knowledge in late-nineteenth-century Britain. Fresh air became one of the central elements of modern theories of hygiene and sanitation, while bacteria was added to the list of dangerous elements in foul air, both indoor and outdoor, along with carbon dioxide, waste poisons from human respiration, and dust. ${ }^{11}$ Miasmic theories of sickness had by the late nineteenth century

\footnotetext{
${ }^{9}$ Alain Corbin, The Foul and the Fragrant: Odor and the French Social Imagination, (Cambridge, MA: Harvard University Press, 1986), pp. 11-21, 89-100, 161-70.

${ }^{10}$ Stephen Mosley, 'Fresh Air and Foul: The Role of the Open Fireplace in Ventilating the British Home, 18371910.' Planning Perspectives, 18 (2003): 1-21; Stephen Mosley, 'The Home Fires: Heat, Health and Atmospheric Pollution in Britain, 1900-45,' in Mark Jackson (ed.), Health and the Modern Home, pp. 196-223 (Routledge: New York, 2007).

${ }^{11}$ Mosley, 'Fresh Air and Foul': 1-9; Mosley, 'The Home Fires', p. 211.
} 
been refuted by modern science, but these earlier ideas about fresh and foul air continued to influence the public debate on air, health, and hygiene in Britain, Europe, and beyond.

As an extension of the health effects ascribed to fresh air introduced into the indoor environment, fresh, outdoor air was considered in modern medicine to have a general therapeutic effect. Many experts on medicine and hygiene considered urban life generally unhealthy and advocated spending more time in an outdoor environment with ample fresh air and sunshine, spurring off a nature discourse promoting the return to pre-industrial society free of the ills of urbanization. More specifically, fresh air, together with sunshine, came to be the preferred treatment for tuberculosis and rickets in open-air sanatoria and health spas. Open-air treatment comprised a combination of light exercise, a special diet, rest, and exposure to fresh air for patients infected with pulmonary tuberculosis, or consumption, in Europe and North America beginning in the 1840s. Following the discovery in 1882 that tuberculosis was caused by tubercle bacillus and the growing knowledge that sunlight had a bactericidal effect, these sanatoria were architecturally designed to expose patients to open air and sunlight. New research into the healing effects of sunlight and ultraviolet radiation was done after the turn of the century. These healing techniques were developed further by Dr Auguste Rollier (1874-1954), ${ }^{12}$ who 'pioneered a form of treatment which was a development of open-air methods in which very slow tanning in cool conditions was combined with rest, fresh air, nourishment and exercise, with the aim of strengthening his patients and improving their resistance to the disease'. ${ }^{13}$ The British Sir Henry Gauvain (1878-1945), sharing Rollier's conviction that sunlight and fresh air had a general therapeutic effect on many diseases, redesigned British hospital wards for the chronically ill by moving beds onto long outdoor terraces to optimize exposure to sunlight and fresh air with good ventilation. ${ }^{14}$ Gauvain was also convinced that these principles of exposure to sunlight and fresh air in well ventilated rooms should be applied not only to patients in hospital wards but also to healthy people in private houses and schools. ${ }^{15}$

Open-air sanatoria were beyond the reach of many less well-off tuberculosis patients in urban Europe and North America. Open-air cure stations offering fresh air and sunshine rather than expensive medical care for workers and poor citizens with tuberculosis were opened in the vicinity of urban centres. In 1904 the first open-air schools, or forest-schools, were established for sickly, anaemic children and children suffering from 'pre-tuberculosis'

\footnotetext{
${ }^{12}$ R. A. Hobday, 'Sunlight Therapy and Solar Architecture', Medical History 42 (1997): 455-9.

${ }^{13}$ Ibid., 459.

${ }^{14}$ Ibid., 466-9.

15 Ibid., 469-71; Mosley, 'The Home Fires', p. 202; Simon Carter, Rise and Shine: Sunlight, Technology and Health (Oxford and New York: Berg, 2007); Susan Barton, Healthy Living in the Alps: The Origins of Winter Tourism in Switzerland, 1860-1914 (Manchester and New York: Manchester University Press, 2008).
} 
and incipient tuberculosis. In ensuing years, hundreds of open-air schools were opened all over Europe, North America, and Australia. The architecture and design of these institutions, with sliding doors and large verandas meant to let in fresh air and sunshine, had an impact on architectural innovations during the interwar period. These schools for anaemic and sickly children exhausted their function, however, after the Second World War when a vaccine for tuberculosis ended the spread of the disease in Europe and beyond. Tuberculosis sanatoria throughout Europe, in particular in the Alps, were then redesigned and became spas for health seekers and tourists, ${ }^{16}$ while the hygiene movement and the pursuit of cleanliness ensured the prevailing prominence of fresh air for healthy living.

The benefits of fresh air, sunshine, and nature, the need for exercise, open windows and doors, and ventilation of rooms for the ill as well as ordinary citizens were all essential parts of the hygiene movement in the West from the nineteenth century until the Second World War, which was aimed at strengthening the modern citizen against foul air, germs, sickness, and consumption. Suellen Hoy has described the American pursuit for hygiene in the late nineteenth and early twentieth centuries as a 'cleanliness crusade', largely a war on filth, foul odours, and miasmas arising from decomposing organic wastes. Although sanitarians 'were inclined to accept the germ theory, they still thought that disease among the poor was largely the result of "filthy habits"".${ }^{17}$ Miasmic interpretations of the causes of infectious disease were dominant in America well into the 1920s. The pursuit of cleanliness in America was largely a battle against filthy things and foul smells, using the 'weapons' of soap, water, modern plumbing, pipes, drains, fans, and ventilation, and last but not least, modern education. ${ }^{18}$

The public sphere in China developed rapidly and became a fairly unrestricted space for public debates following a marked increase in the number of newspapers and journals published and distributed in the 1880s and 90s, and this was even more so after the Chinese defeat in the 1894-95 Sino-Japanese War. Intellectuals and reform-minded scholar-gentry engaged in the exchange of ideas about cultural, social, and political matters like international relations, national identity and strength, health, and hygiene, modern science, language, history, and many more. Reformers in late-nineteenth-century China recognized that Chinese

\footnotetext{
${ }^{16}$ Anne-Marie Châtelet, 'A Breath of Fresh Air: Open-Air Schools in Europe', in Marta Gutman and Ning De Coninck-Smith (eds.), Designing Modern Childhoods: History, Space, and the Material Culture of Children, pp. 107-27 (New Brunswick, NJ: Rutgers University Press, 2008); Linda Bryder, 'Wonderlands of Buttercup, Clovers, and Daisies': Tuberculosis and the Open-Air School Movement in Britain, 1907-39', in Roger Cooter (ed.), In the Name of the Child: Health and Welfare, 1880-1940, pp. 72-95 (London and New York: Taylor and Francis, 2002); Susan Barton, Healthy Living in the Alps.

${ }^{17}$ Suellen Hoy, Chasing Dirt: The American Pursuit of Cleanliness (New York and Oxford: Oxford University Press, 1995), p. 133.

${ }^{18}$ Ibid., pp. 59-149.
} 
society was facing many challenges similar to the problems of health and hygiene in the West - a physically weak population seemingly unable to fight the dangers of Western and Japanese imperialism, urbanization, an expanding population, and the spread of many contagious diseases - and sought the solution to these challenges of modernity in Western ideas. Among them was the notion of hygiene (weisheng), or 'hygienic modernity' as Ruth Rogaski has named the ideas that were transformed first into theory in China and later also into practical measures of public hygiene. ${ }^{19}$ Hygienic modernity, as a development of the traditional 'guarding life' (weisheng) schemes, began in China with the translation of a few European texts in 1880 and developed into a national movement that had fresh air, air quality, and sunshine as essential ingredients, and ventilation as a solution, in the making of the robust citizen for the modern Chinese nation. The Chinese urban elite, and later also the literate public, was introduced to and learned from this array of Western perspectives on air, miasmas, filth, health, and hygiene. Ultimately, Western miasmic theories of filthy things, foul air, and stagnation causing disease took centre stage in China's pursuit for cleanliness. ${ }^{20}$

\section{Chinese translation, reception, and discourse on air, health, and hygienic modernity}

Chinese modern perceptions of the correlation between air and health, and ultimately between ventilation and the nation, have their antecedents in the history of miasmic medicine described above. Prior to the introduction of modern Western science in China, there was no general term for 'air' in Chinese, and the quality and different properties of air were variably referred to as 'wind' (feng 風), 'hazy air' (mai 霧), 'foggy air'( $w u$ 霧), 'vital energy' ( $q i$ 氣) in traditional Chinese medicine, 'exhale' ( $h u$ 呼), 'inhale' ( $x i$ 吸), 'to blow' (chui 吹), 'howling sound (of the wind)' (xiao 嘯), etc. The Chinese translation of Western-language chemistry books and articles ${ }^{21}$ about air composition as a mixture of several gases commenced in 1849 and mushroomed in the late 1860s. These translations gave scholars, albeit a relatively small circle, access to scientific knowledge about air quality. ${ }^{22}$ With the proliferation of popular journals and basic education for many in the last decades of the nineteenth century and in the early twentieth century, pneumatic chemistry, or air science

\footnotetext{
${ }^{19}$ Rogaski, Hygienic Modernity.

${ }^{20}$ Within traditional Chinese folk medicine, miasmic-like ideas about endemic pestilent vapours referred to as zhangqi (瘴氣) had for a long time directed people's sensitivity towards the relationship between disease and the environment (see e.g., Rogaski, Hygienic Modernity, p. 163). Perceptions about zhangqi were, however, never called upon when ostensibly modern ideas about air quality and health were transmitted and translated from the West and became essential components of China's discourse on health, hygiene, strength, and the nation.

${ }^{21}$ David Wright, Translating Science: The Transmission of Western Chemistry into Late Imperial China, 18401900. (London, Boston, Köln: Brill, 2000); James Reardon-Anderson, The Study of Change: Chemistry in China, 1840-1949 (Cambridge: Cambridge University Press, 1991).

${ }^{22}$ Svarverud, 'The Terminological Battle for "Air" in Modern China'.
} 
(qixue 氣學), came to constitute the basis for the popular perception in China of air as clean, healthy, and life-giving but also as a potential health hazard, spreading foul and excess gases, toxic substances, germs, dust, and other polluting airborne elements. As advocated through modern health science, sources of pollution were to be found everywhere in the environment, including emanating from humans themselves.

The principles of modern hygiene for the individual were introduced from the West in China in the 1880s and 90s by John Fryer (1839-1928) and his colleagues of the Translation Department of Jiangnan Arsenal in Shanghai. The link between air quality and health were central to the theories of hygiene he presented, which he based on European miasmic theories about causes of diseases and how to mitigate them. In a series of 29 articles entitled 'On chemical hygiene' in Chinese Scientific Magazine (1880-1882), based on the book The Chemistry of Common Life (1855) by the Scottish James Finlay Weir Johnston (1796-1855), Fryer and his Chinese co-translators at the Arsenal presented chemistry as the key to understanding the principles of nature. They explained how modern science could be exploited to maintain the health and wellbeing of the individual. ${ }^{23}$ Additionally, Fryer edited and published a series of four articles in Chinese Scientific Magazine in 1890, based on various English language sources, entitled 'On the hygiene of dwellings' (Juzhai weishenglun). In these articles, Fryer presented the potentially adverse health effects of poor quality indoor air and promoted sanitary means to improve household hygiene. ${ }^{24}$ While sickness caused by stagnant, foul air - the result of the presence of human waste in densely populated rooms and quarters - was described as one of the main problems of modern society, sanitary devices for ventilation and the technical management of human refuse would hold the solutions to these problems.

According to Fryer, who was clearly tapping into the current European debates on air, miasmas, and health, air contained pathogenic gases and chemical substances emitted from factories, sewers, decaying organic matter, and from humans breathing. ${ }^{25}$ In spite of the rising influence of germ theory in Europe, germs were perspicuously absent from the disease theories presented in his texts. ${ }^{26}$ Instead, Fryer advanced air as one of the central components in the Chinese modern scientific pursuit of hygiene and good health for the individual. In fact,

\footnotetext{
${ }^{23}$ John Fryer (tr.), 'Huaxue weishenglun’化學衛生論 [Chemistry as the Key to Health], Gezhi huibian 格致彙 編 spring, no. 3 (1880): 10a-10b and 4 no. 12 (1882): 5a-9b. In 1890 these texts were published as a book with the same title by the Chinese Scientific Book Depot (Gezhi shushi 格致書室) in Shanghai. See also Rogaski, Hygienic Modernity, pp. 104-5.

${ }^{24}$ John Fryer (tr.), ‘Juzhai weishenglun’ 居宅衛生論 [On the Hygiene of Dwellings], Gezhi huibian 格致彙編 spring (1890): 27a-29b, summer (1890): 14a-17b, fall (1890): 14a-17b, winter (1890): 28a-33b. See also Rogaski, Hygienic Modernity, pp. 124-5.

${ }^{25}$ Fryer, 'Huaxue weishenglun', 1890, p. 12b; 'Juzhai weishenglun' spring (1890): 27a-28a.

${ }^{26}$ Rogaski, Hygienic Modernity, pp. 108-15.
} 
the modern ideas of hygiene expressed by Fryer - a focus on the health of the individualremained in vogue until 1900 when ideas about weisheng (Jap. eisei), transmitted from the West via Japan to China, shifted the focus onto public hygiene. ${ }^{27}$ In the early twentieth century, the need to pursue cleanliness began to be disseminated to the broader Chinese public, beyond the narrow circles of intellectuals and translators. These ideas, in line with Fryer's translations, advanced European miasmic theories of diseases and were heavily influenced by the then current Japanese discourse on public hygiene. The Chinese discourse on public hygiene, inspired by multiple new sources in foreign popular and scientific literature, highlighted four main elements in its association of air and public health, fresh air, dust, germs, and sunshine, reinforced by the conviction that ventilation was crucial for maintaining good health. All of this was fashioned into China's national quest for hygienic modernity with healthy and robust citizens, and at its core, the indispensability of clean and fresh air.

\section{Air quality and health in China's quest for cleanliness}

Clean (qingjie 清潔) air in the Chinese public discourse was associated with air free from polluting industrial elements, most often referred to as 'smoke' (yanwu 烟雾). A 1906 article in the Chinese magazine $A$ Review of the Times correlated unclean air with poor hygiene in foreign cities: 'In all major industrial cities, smoke is excessive and often blocks half the sky. Then, the air is not clean (qingjie) and hence detrimental to hygiene. London, England is one such example'. ${ }^{28}$ The idea of fresh air (xinxian kongqi 新鮮空氣) as essential for public hygiene entered the Chinese debate about a decade later. China had at this point no large-scale modern industry, ${ }^{29}$ and ambient air pollution had not yet become a social and environmental issue (which it did only with reform and the opening up of China after 1978). Judging from the public's engagement in the Chinese discourse on air and health, the need for fresh indoor air had a much greater appeal to the general readership than reports on smoke from factory stacks in foreign cities like London. Two articles translated from foreign languages published in $1916^{30}$ were followed by an array of articles in the Chinese press on fresh air. They reiterated ideas about the general therapeutic effects of fresh air made popular in the European debates. These articles accentuated how human breathing caused oxygen depletion and raised levels of carbon dioxide in crowded domestic spaces. Furthermore, the waste-poisons

\footnotetext{
${ }^{27}$ Ibid., pp. 136-64.

28 ‘Qingjie kongqi’ 清潔空氣 [Clean Air], Wanguo gongbao 萬國公報, 215 (1906): 87.

${ }^{29}$ Wang Yangzong, 'Jindai gongye'.

30 'Xinxian kongqi' 新鮮空氣 [Fresh Air], Yingyu zhoukan 英語周刊 52 (1916): 1328-31; 'Xinxian kongqi zhi yanjiu’ 新鮮空氣之研究 [Investigations into Fresh Air], Kexue 科學 2, no. 3 (1916): 281-99.
} 
produced by human exhalation added to the potential dangers of respiring in confined spaces. An article entitled 'Essentials of hygiene: The importance of fresh air' published in 1918, elucidated the dire consequences of dwelling or sleeping in an area with too little fresh air and no ventilation:

One oil lamp and one candle can also cause the air to become foul, in the same way as when several people are gathered in one room causing the air to become foul. One coal fire, equal to 30 to 40 people breathing in one room, will quickly cause the indoor air to become exceptionally foul. In winter, people often like to close doors and windows and light an indoor fire. Then, while sleeping one buries one's head [in the pillow], which is very dangerous as one will suffer from lack of fresh air. If one lights an indoor fire with doors and windows closed, it may cause the loss of lives, and even if one is lucky not to die, the blood will be saturated with poisonous substances and the skin will change to a yellow-greenish colour. If one sleeps with their head buried and heats without restraint, then one will be poisoned by foul air. Breathing and re-breathing, over and over again, will have dire consequences for humans. ${ }^{31}$

Reflecting the shift in Western theories about the causes of diseases, Chinese miasmic theory about human waste-poisons as the main cause of indoor suffocation and disease was replaced in the mid-1920s by the modern scientific idea that dust, carbonic acid gases, ammonia, and other chemical compounds in the air were the main indoor pollutants. Commitment to the rationalization of the science of chemistry gained ground in public discourse. The importance of fresh and clean indoor air did, however, not lose its former importance, it only took on new meanings as expressed by He Zhu's concern for the adverse health effects of chemical waste gases of human and animal breathing in a 1925 article:

Carbonic acid gases accumulate in air when humans and animals breathe and when plants and wood are burned. This can cause human breathing to become laborious and may induce dizziness and other disorders. In the air [under such circumstances], there will also often be ammonia, which is an irritating, suffocating, and corroding gas, and therefore it should not be inhaled. The air may contain evaporated substances, and therefore often water damp [forms], which may facilitate the propagation of pathogenic bacteria. ${ }^{32}$ Lack of fresh air became the causal explanation for many human psychological ailments in the 1930s, described as 'feelings of displeasure', 'unsuccessfulness', 'dispiritedness', 'lack of energy for school work', 'dizziness and headache', 'lack of appetite', as well as 'physical

\footnotetext{
${ }^{31}$ Su Qingxin 蘇清心, ‘Xinxian kongqi zhi jinyao’ 新鮮空氣之緊要 [The Importance of Fresh Air], Shizhao yuebao 時兆月報 12/12 (1918): 20 .

${ }^{32} \mathrm{He}$ Zhu 何鑄, 'Shizhong kongqi jianchafa yu qingjiefa' 室中空氣檢查法與清潔法 [Methods for Examining and Cleaning Indoor Air], Shiye qianshuo 實業淺說 317-318 (1925): 35-6.
} 
signs of fatigue'. ${ }^{33}$ In contrast, open windows and access to an ample amount of fresh air would boost one's energy and state of mind, described as 'a psychological sense of clarity', 'a bodily sense of pleasure', 'feelings of happiness in all matters', and 'mental satisfaction and pleasure' ${ }^{34}$ We have seen how fresh air entered the Chinese discourse of health in the $1910 \mathrm{~s}$ as a condition for a physically strong body and took on the further indispensable role in China in the 1930s of fostering mentally sound citizens. This trend of linking fresh air with healthy bodies that would in turn build a strong society and nation was taken up in the 1930s and 40s when European ideas that urban life was unhealthy and that fresh air, sunshine, and rural living were therapeutic also reached China. Frequently, contributions to the Chinese discourse on healthy living idealized rural life rather than urban because of the lower population density and hence better air quality in rural areas. ${ }^{35}$ An article in a Chinese educational magazine laid out the main reason for rural people being healthier and more sturdy than urban citizen: 'the air they breathe is different. To put it simply, the reason is that rural people breathe fresh air while urban people breathe foul air'. The article continued by expounding on the physiological linkages between air and health and the benefits of fresh air in making individuals more 'fit for survival', to frame it in the ever so popular Darwinian jargon in China at the time:

Air is the most important thing for people, even more important than food. When one eats superior food, then the body will gain appropriate nutrients and will grow stronger. In contrast, if one eats inferior food that does not contain sufficient nutrients, then the body will become bony and frail. This is a very obvious principle. When it comes to air and people, it is the same way. If one breathes fresh air, then the blood will be clean, digestion will be excellent, and every limb will be sturdy. And if there are pathogenic bacteria assaulting the body, they will be eliminated by a strong resistance and no illness will occur. In contrast, if one breathes foul air, then the blood will be unclean, digestion will be inadequate, one will be low in spirits, and the body will get weaker by the day.

\footnotetext{
${ }^{33}$ Zhijian 志堅, 'Zenyang dedao xinxian kongqi' 怎樣得到新鮮空氣 [How to Obtain Fresh Air], Ertong kexue $z a z h i$ 兒童科學雜誌 1, no. 8 (1934): 25-30; ‘Huxi xinxian kongqi’ 呼吸新鮮空氣 [Breathing Fresh Air], Budao $z a z h i$ 佈道雜誌 7, no. 3 (1934): 56-7; Zhao Lin 趙琳, 'Riguang he xinxian kongqi' 日光和新鮮空氣 [Sunlight and Fresh Air], Guangxi weisheng xunkan 廣西衛生旬刊 2, no. 35 (1935): 10-11.

${ }^{34}$ Zhijian, 'Zenyang dedao xinxian kongqi'; Wu Xingye 吳興業, 'Xinxian kongqi yu riguang’ 新鮮空氣與日光 [Fresh Air and Sunshine], Jing-Hu Hu-Hang tongtielu rikan 京渥渥杭通鐵路日刊 832 (1933): 157-8. ${ }^{35}$ Zhijue 之覺, 'Xinxian kongqi heyi zhongyao' 新鮮空氣何以重要 [Why Fresh Air Is Important], Zhongxuesheng 中學生 11 (1930): 5-6.
} 
For a juvenile, every part of the body will be unable to develop fully. This is precisely the reason why there is a difference in strength between urban and rural people. ${ }^{36}$ Air could, in the Chinese discourse, become contaminated and hence made un-fresh and potentially hazardous for humans by a number of polluting factors, the two most important being dust and bacteria. Dust (chen'ai 塵埃) entered the Chinese discourse on clean air as a potential health hazard and a component of impure air as early as the beginning of the twentieth century in an article on dust in Berlin. ${ }^{37}$ In the ensuing debates, dust was frequently perceived as a transmitter of miasmas and later as a carrier of bacteria, or the 'wings of bacteria,' as it was referred to. ${ }^{38}$ In line with the influence of miasmic theories of diseases in China prior to the mid-1920s, dust was primarily believed to be small particles emitted from decaying matter. Knowledge of the harmful health effects of inhaling dust particles and the capability of dust dispersed in air to transmit infectious and even deadly diseases was conveyed through a series of articles in Chinese magazines in the mid-1910s. ${ }^{39}$ Dust was perceived as potentially harmful to humans, but the modern science of cleanliness offered remedies. The article 'The dangers of dust', first published in Women's Magazine in 1914, referred to experiments performed by a foreign scientist measuring the concentration of bacteria in indoor air before and after sweeping. The experiments proved that the number of dust particles carrying bacteria in the air was drastically reduced hours after cleaning. ${ }^{40}$ This very promising scientific evidence for the effects of modern hygiene and cleaning techniques was well received and the text was reprinted several times between 1914 and 1936. Dust had become an object of modern science, and this was conveyed to the younger generation. An article in the magazine Chinese Children's World cautioned the young generation of the dangers of indoor dust, while explaining that by practicing proper cleaning techniques these dangers could be avoided:

Dust particles in the air are in fact very numerous. If one is indolent with cleaning, then indoor rooms will be full of dust. If one is a person of cleanliness [on the other hand], then one will wipe rooms until they are tidy and clean. ${ }^{41}$

\footnotetext{
${ }^{36}$ Lun 倫, 'Zhao xinxian kongqi qu' 找新鮮空氣去 [Searching for Fresh Air], Minzhong jiaoyu banzhoukan 民 眾教育半周刊 1, no. 34 (1930): 2-3.

37 'Kongqizhong zhi chen'ai' 空氣中之塵埃 [Dust in the Air], Dalu 大陸 3 (1903): 8; 'Boling zhi chenai jianchafa' 伯靈之塵埃檢查法 [Inspection of Dust in Berlin], Dalu 大陸 14 (1905): 4-5; Hua Hong 華鴻, 'Kongqi' 空氣 [Air], Yiyao xuebao 醫藥學報 10 (1908): 116-7.

38 Tian Yi 天翼, ‘Chen'ai zhi gongyong’ 塵埃之功用 [The Functions of Dust], Jinbu 進步 3, no. 6 (1913): 111.

${ }^{39}$ E.g. 'Chen'ai yu shengming zhi guanxi' 塵埃與生命之關係 [The Relationship between Life and Dust], Youxi zazhi 遊戲雜誌 7 (1914): 3; 'Chen'ai wei chuanyi zhi mei’ 塵埃為傳疫之媒 [Dust as a Transmitter of Disease], Datongbao 大同報 20, no. 26 (1914): 41.

40 ‘Chen’ai zhi weixian’ 塵埃之危險 [The Dangers of Dust], Funü shibao 婦女時報 15 (1914): 31-2.

41 ‘Chen'ai zhi zuoyong’ 塵埃之作用 [The Utilities of Dust], Zhonghua tongzijie 中華童子界 8 (1915): 29-34.
} 
The germ theory of disease was systematically introduced into China in the early twentieth century and began to influence the medical discourse in the $1910 \mathrm{~s},{ }^{42}$ but for the general public, airborne bacteria as a cause of disease was only briefly alluded to. In the mid-1920s, however, the ostensibly modern scientific perspective on bacteria in foul air flourished in student, agricultural, and hygiene periodicals. Germs became the modern foe of cleanliness in China. Foul air came to be associated with bacteria-transmitting diseases, and modern hygiene was engaged as the science that would ensure health and progress as described in an article in the magazine Farmer in 1928:

People like us, regardless of what activities we engage in, rely entirely on a healthy body. Only then will we be able to progress, which is something that everybody knows. A healthy body relies entirely on clean blood, because only when the blood is clean can it circulate freely and fully supply nourishment [to all parts of the body].... For the blood to be clean, the air needs to be fresh. If one dwells in foul air, which contains lots and lots of microbes, we will inhale them into our lungs and we will develop respiratory diseases.... So, our homes and schools must frequently be wiped clean so that dust does not accumulate. $^{43}$

As we have seen, the discourse of public hygiene and health in China throughout the first half of the twentieth century had, as an essential prerequisite for a good life and a prosperous society, fresh air free from dust particles and bacteria. As in Britain and across Europe, access to ample amounts of sunshine was also a constituent condition for a healthy life, a strong body, and a prosperous society in China. Fresh air, sunshine, and subsequently effective ventilation of indoor spaces would, in China, be associated with the strength of the collective population and the Chinese nation as such, as we shall see below.

\section{Sunshine and ventilation for public health and modern living}

When the necessity of sunlight for photosynthesis in plants was introduced into the Chinese scientific debate, again inspired by Western scientific literature, its life-giving power was also discursively extended to all living creatures; plants, animals, and humans would only be physically strong when they were exposed to sunlight, and, conversely, lack of sunlight would weaken any living organism. Rural life with ample access to sunshine became the ideal. In medical circles, these perspectives dominated the discourse on hygiene, general healthiness,

\footnotetext{
${ }^{42}$ Bridie J. Andrews, 'Tuberculosis and the Assimilation of Germ Theory in China, 1895-1937', Journal of the History of Medicine and Allied Sciences 52, no. 1 (1997): 114-57; Rogaski, Hygienic Modernity, p. 173. ${ }^{43} \mathrm{Wu}$ Kuiwu 吳奎五, 'Riguang kongqi yu rensheng de guanxi' 日光空氣與人生的關係 [The Relationship between Sunlight, Sun and Human Life], Nongmin 農民, 3, no. 33 (1928): 10.
} 
and medical treatment from the early 1910s, observable, for example, in a 1912 article in a medical journal entitled 'On the hygienic benefits of sunshine':

The sun is one of the planets, bright and colourful, warm and genial. It has the ability to transform and nourish all things, so our bodies should frequently be exposed to its radiation in order to safeguard our happiness. If not, then our bodies will wither and we will easily contract diseases. If one resides in a dark room for long, then the blood will dwindle. The physiology of the body depends entirely on the scarlet coloured blood. If the blood is weak, then the person will be weak and will contract diseases.... Even if the homes of wealthy people are beautiful, they often lack sufficient sunshine. So, when comparing rich people and rural people, one of these groups has weak bodies and pale faces, the other has strong bodies and ruddy faces. ${ }^{44}$

The therapeutic effects of sunshine on tuberculosis and various other ailments espoused in Europe by Rollier, Gauvain, and others were introduced into medical circles in China during this time and put into practice in Chinese medical institutions and hospitals in the latter half of the 1920s:

Any weak person will be strengthened by frequent exposure to sunlight. This has been known to all for a long time. Regarding the healing effect of sunbathing on many different diseases, it seems that this has not been common knowledge before. It is only now that [such treatment] has shown to have many different effects which then prove that the above statement is true..$^{45}$

Physical strength, competitive advantage, and survival were the aims of a successful modern national subject, framed by the conditions presented in the Chinese interpretation of Darwinism, ${ }^{46}$ and foul air, dust, and bacteria were considered to be latent threats to a strong and healthy body. Substantiated by science, a middle-school student in 1930 claimed that 'sunshine and air...constantly wage war against fatal dust!' ${ }^{47}$ Exposure to ample quantities of fresh air and sunshine was the way to kill bacteria and nurse tuberculosis patients. As an essential ingredient in China's nature discourse promoting rural living, sunshine was also believed to be a beauty aid for young, modern women, and by the 1920s, promoted in the public discourse as an important element in the furthering of the aspirations and strengthening

\footnotetext{
${ }^{44}$ Zhang Ruoxia 張若霞, 'Lun riguang zhi youyi yu weisheng' 論日光之有益於衛生 [On the Hygienic Benefits of Sunshine], Zhong-Xi yixuebao 中西醫學報 1912: 7-8.

${ }^{45}$ Ting 霆, 'Riguangyu zhi liaobingfa' 日光浴之療病法 [The Therapeutic Effects of Sunbathing], Xiehebao 協 和報 5, no. 5 (1914): 16. See also photos of these therapeutic methods applied in China and abroad in: Xieyi xiaokan 協醫校刊 2 (1927): 139; Ertong shijie 兒童世界 20/21 (1927): 2, 8; Shizhao yuebao 時兆月報 23, no. 2 (1928): 21.

${ }^{46}$ James Reeve Pusey, China and Charles Darwin (Cambridge, MA and London: Harvard University Press, 1983).

${ }^{47}$ Yun Bing 允冰, ‘Chen’ai zhi hua’ 塵埃之話 [Talk on Dust], Zhongxuesheng 中學生 7 (1930): 5.
} 
of the individual body and the collective body of the Chinese nation-state. Leading an outdoor life exposed to sunshine was healthy, while indoor living was healthy on the condition that the air was kept fresh through exchange with the outdoor environment.

Ventilation of indoor air to exchange fresh air between indoor and outdoor environments was perceived to be the solution to the hygienic challenges posed by foul indoor air. Again, the sources of inspiration for China's educated public when 'engineering freshness', to employ Vladimir Janković's terminology, were mainly British. Ventilation has a long medical history in Britain. 'Conceived initially to combat fevers, its eighteenth-century advocates described it as a solution in places plagued by overcrowding, humidity, stale air, and putrid exhalations'. ${ }^{48}$ Miasmic theories informed people in Britain and Europe that stagnant water and air were detrimental to health, as were waste poisons from human respiration. Indoor depletion of oxygen, rising levels of carbon dioxide and waste poisons, often referred to as human miasma, would cause headaches, dizziness, nausea, and ultimately death. ${ }^{49}$ Heating and open fires were already in eighteenth-century Britain considered to be the best solution to ventilate public buildings, ships, gaols, hospitals, and private homes. Consequently, a healthy indoor home environment could only be ensured by effectively venting out vitiated air, and the best way to do so was to create a flow of air through the building by firing the open hearth. The challenge was to balance the need for ventilation with a comfortable indoor temperature and the prevention of indoor drafts. ${ }^{50}$ In addition, in Victorian British cities like London, Liverpool, Manchester, and Glasgow, ambient air was polluted by smoke from factory stacks, and letting in outdoor air to clean the indoor environment was not necessarily the ideal solution. Additionally, in 1880 Francis Albert Rollo Russel claimed in the publication London Fogs that a major polluting source in British cities was, in fact, home fires. When smoke from open coal fires in urban British homes fused with emissions from factory stacks in winter months, the result was a fatal combination of gases and aerosols in the air that accounted for thousands of premature, respiratory-related deaths each year. Emissions from private homes were caused by home fires that were lit in efforts to ventilate homes. ${ }^{51}$ In spite of growing concern with ambient air quality, ventilation of homes was advocated for ensuring public health.

An adult person would pollute about 3000 cubic feet of air per hour according to scientific calculations. Based on this calculation, Francis Stephen Bennett François de

\footnotetext{
48 Vladimir Janković, Confronting the Climate: British Airs and the Making of Environmental Medicine (New York: Palgrave Macmillan, 2010), p. 69.

${ }^{49}$ Mosley, 'The Home Fires', p. 211.

${ }^{50}$ Ibid., pp. 67-84.

${ }^{51}$ Mosley, 'Fresh Air and Foul': 1-4.
} 
Chaumont (1833-1888) created a table of safe dwelling times for humans in rooms of different sizes. An average middle-class home was estimated to have a volume of air that was sufficient for only 20 minutes of safe breathing. This meant that the air had to be replaced at least three times per hour. Unfortunately, most people in Britain had far less indoor space for breathing and would have to ventilate a room every four to five minutes to ensure acceptable air quality. ${ }^{52}$ Ventilation in this literature was divided into two kinds, mechanical and natural. Mechanical ventilation entailed the installation of pumps, blowers, and fans, while natural ventilation was the only way to comply with these health standards for indoor air for less affluent Europeans. Natural ventilation meant open windows and doors, ventilating shafts, air vents in walls, but most importantly, open fires. ${ }^{53}$ These modern British and European ideas of air, ventilation, and public health were then translated and introduced into China in the late nineteenth century and formed the basis of the Chinese public discourse on ventilation.

John Fryer and his team of scientific translators were the first to introduce the scientific link between air quality and health in China, and also the first to address chemical and mechanical solutions to indoor air quality problems to a Chinese readership. Fryer's two publications discussed above laid down the foundation for a Chinese discourse on how to deal with foul indoor air. 'On the hygiene of dwellings', published in 1890, marked the onset of a Chinese discourse of the means to ensure a healthy home environment through ventilation. It appears that Fryer selected texts and illustrations from different British, and possibly also North American, publications on building techniques for a healthy home environment, hygiene in homes and institutions, sanitary installations and equipment, and ventilation and heating of buildings for this Chinese publication. Fryer explained that natural air contained only small amounts of carbon dioxide while in closed rooms the percentage of this gas could, because of human respiration, reach levels detrimental to health and even cause death. This waste gas, detected by its foul smell, could also be mixed with germs, and condensate on cold surfaces into water droplets that contained hazardous elements. In addition to these sources of indoor air pollution, lit lamps and candles together with moist and putrefying matter on the floor, like dead mice and insects, all contributed to foul indoor air. ${ }^{54}$ Ventilation was recommended by Fryer both in urban and rural homes: 'It is difficult for humans to obtain clean indoor air. Even in rural areas where there are few people one has to take ventilating precautions not to let foul air attack human [health]'. ${ }^{55}$

\footnotetext{
${ }^{52}$ Ibid., 9-11.

53 Ibid., 11-19.

${ }^{54}$ Gezhi huibian 格致彙編 summer (1890): 14a.

55 Ibid., 14b.
} 
In 'On the hygiene of dwellings', Fryer expounded further on the calculations to determine the amount of fresh air and ventilation (tongfeng 通風) needed to maintain a healthy environment, and Francis de Chaumont's prescription for the exchange of air three to four times per hours is recognisable. Fryer richly illustrated how to ensure the necessary flow of fresh air through windows, doors, and air vents, the configuration of modern ventilating shafts and valves, the function of chimneys, and the construction of open and closed fireplaces. ${ }^{56}$ The need for ventilation and exchange of air between the outdoors and the indoors must have appeared urgent to the concerned Chinese readers of this text, while all the technical prescriptions for how to install shafts, air vents, and fireplaces were unworkable in most houses in late nineteenth-century China. 'On the hygiene of dwellings' was never published as a separate book following its publication in Chinese Scientific Magazine and does not seem to have had much influence on the ensuing public debate in China. As Rogaski says, 'Juzhai weishenglun escaped attention because it offered little information of practical use to an individual Chinese reader'. ${ }^{57}$

The second, and potentially more significant, wave of interest in ventilation in China was spurred on by influence from the East rather than from the West. Japan had opened up to science and new knowledge from Europe and North America earlier and on a much more comprehensive scale than China. After Chinese students started attending modern educational institutions in Japan in $1896,{ }^{58}$ many novel modern scientific ideas trickled back to China in publications by Chinese students in Japan in the early years of the twentieth century. The most comprehensive source of the new knowledge being introduced into China from Japan was the extensive 100-volume modern encyclopaedia Baike quanshu published in Shanghai in 1903, the first of its kind. In several volumes on chemistry, meteorology, physiology, and bacteriology, readers had access to updated scientific knowledge on topics like air, the atmosphere, gases, germs, breathing, human waste gases, and ventilation. The volume on everyday chemistry (riyong huaxue 日用化學) contained information on the principles of how bacteria attached themselves to dust particles disseminated in the air, causing organic matter to decay when it came in contact with air. ${ }^{59}$ These processes were not linked to human breathing, health, and sickness in this volume. Breathing, waste gases, and hygiene were, however, discussed in the volume on physiology (shenglixue 生理學), where no mention of

\footnotetext{
${ }^{56}$ Ibid., 14b-17b; fall (1890): 14a-16a.

${ }^{57}$ Rogaski, Hygienic Modernity, p. 125.

${ }^{58}$ Paula Harrell, Sowing the Seeds of Change: Chinese Students, Japanese Teachers, 1895-1905 (Stanford CA: Stanford University Press, 1992).

${ }^{59}$ Fan Diji 范迪吉 (ed.), Baike quanshu 百科全書 [Complete Book on All Subject Matters] vol. 88, pp. 5b-6a (Shanghai: Huiwen shushe, 1903).
} 
bacteria as a cause of respiratory diseases was made. The author of this volume explained how waste gases from human respiration concentrated in inhabited rooms and around people's beds while they were sleeping. Sick people's rooms had to be treated with great caution as the air these patients exhaled was more detrimental to human health than the wastegases from healthy humans, according to the encyclopaedia. ${ }^{60}$ The text concluded with the necessity to ventilate rooms to ensure a healthy indoor environment: 'Therefore, the exchange of fresh and depleted indoor air should follow these principles: One [air vent] should be located to introduce outdoor air, another located to remove indoor air'. ${ }^{61}$

These ideas about modern living, public hygiene, and ventilation were disseminated discursively to a much broader audience, commencing with an article entitled 'Five ventilating techniques for buildings' in 1905. Other contemporary articles advanced ideas of how human miasma and carbonic gases accumulated in rooms and promoted techniques for how to ventilate rooms through the fitting of ventilating holes and slits in walls. These articles frequently demonstrated great optimism about solutions offered by modern engineering when calculating the ratio of air exchange between indoors and the outdoor environments, such as using different sized holes in a wall to enhance ventilation. ${ }^{62}$

The two types of ventilation, mechanical and natural, that were presented in the British debate were also introduced in China. In specialised magazines and books on engineering and hygiene from 1915, mechanical fans were presented as an effective means of ventilating buildings. ${ }^{63}$ In the early 1930s, technical installations for the ventilation of buildings also entered the public imagining of modern living. Magazines and journals were filled with pictures and illustrations of attractive modern rooms and indoor architecture with ample light and fresh air, supplied through natural ventilation and through the installation of fans, tubes, and shafts. According to these articles, modern living in China was expected to be ventilated and sunlit. ${ }^{64}$ In the latter half of the 1930 s, ventilation of public space with ample access to air

\footnotetext{
${ }^{60}$ Ibid., vol. 7, pp. 39b-41a.

61 Ibid., p. 41a.

62 'Zhushi tongfeng wushu' 築室通風五術 [Five Ventilating Techniques for Buildings], first printed in Shangwubao 商務報 69 (1905): 40-2, later reprinted in other journals in 1907 and 1935; Huang Zhenhong 黃振 洪, ‘Weshenglun’ 衛生論 [On Hygiene], Kexue 科學 1, no. 12 (1915): 1407-10.

${ }^{63} \mathrm{Xu}$ Shida 徐世大, 'Fangwu kongqi zhi tongfeng' 房屋空氣之通風 [Ventilation of House Air], Beiyang daxuexiao jikan 北洋大學校季刊 1 (1915): 20-7.

${ }^{64}$ E.g. 'Cunshe jianzhu guangxian kongqi jie ji chongzu’ 村舍建築光線空氣皆極充足 [Sunlight and Air Are Ample in Rural Buildings], Xiao shijie 小世界 34 (1933): 31; 'Shizhong kongqi de huanliu’ 室中空气的环流 [Circulation of Indoor Air], Kexue huabao 科学画报 2, no. 10 (1934): 391; 'Wuding tongfengqi' 屋顶通风器 [Rooftop Ventilation Equipment], Kexue huabao 科学画报 2, no. 4 (1934): 142; 'Chuanghu yao duokai shi kongqi liutong' 窗戶要多開使空氣流通 [Windows Must Frequently Be Kept Open to Ventilate Air], Xin shenghuo zhoukan 新生活周刊 1, no. 12 (1934): 2.
} 
and sunshine also entered the Chinese public discourse on modern living. ${ }^{65}$ However, serious concern over poor quality ambient air never surfaced in the Chinese discourse on the ventilation of homes and buildings during this period before 1949. Outdoor air pollution became a public concern in China only after 1978.

\section{Education in air cleanliness, hygiene, and ventilation for the nation}

An urgent task for the new republican government in China after 1912, following the fall of the last dynasty, was to create national subjects of the newly established state, and an essential part of this strategy was to foster healthy and strong modern citizens through the new educational system. ${ }^{66}$ Modern science, and in particular the modern scientific knowledge of public health and hygiene that developed out of the translations and discourse discussed above, became a central aspect of this educational project. The first set of textbooks for advanced primary school students published in 1912 stressed the importance of air quality for health:

If the air is impure, it will be harmful for respiration. If one spends a long time in a theatre or in a store, one may feel dizzy and giddy. That is for no other reason than because of impure air. Anyone familiar with [the principles of] hygiene [knows] that rooms must be spacious and windows must frequently be opened. When one has some spare time, one should play in the countryside. When the air is clear and fresh, then it will be of great benefit for the body. ${ }^{67}$

Perspectives on clean air disseminated to advanced primary school students at this time were, as we see, mostly related to the idea that sufficient indoor space and ample amounts of clean air for breathing, which could be supplied through open windows, were needed. Gases from human waste, dust, and germs in the air were not yet on the educational agenda. When, however, a set of textbooks for the revised curriculum in Chinese schools were published in 1923-1924, adapted for the 1922 Educational Reform, ${ }^{68}$ hygiene (weisheng) had become a separate subject for the advanced years of primary schools, and a set of four volumes of textbooks on hygiene were published for these students. An entire chapter was dedicated to

\footnotetext{
${ }^{65}$ E.g. 'Xin shenghuo yu zhuzhai gailiang' 新生活與住宅改良 [New Living and Improvement of Housing], Xin jianzhu 新建築 1 (1936): 3-6; 'Zhuzhai wenti zhi yanjiu' 住宅問題之研究 [Investigations into Questions on Housing], ibid., 2 (1936): 17-21; 'Lixiang de dushi’ 理想的都市 [Ideal Cities], Zhishi huabao 知識畫報 3 (1937): $10-1$.

${ }^{66}$ Xiaoping Cong, Teachers' Schools and the Making of the Modern Chinese Nation-State, 1897-1937 (Vancouver, BC, Toronto, ON: UBC Press, 2007), pp. 71-7; Suzanne Pepper, Radicalism and Educational Reform in 20th-Century China: The Search for and Ideal Development Model (Cambridge: Cambridge University Press, 1996), p. 61; Zarrow, Educating China, pp. 26-40.

${ }^{67}$ Gongheguo jiaokeshu一Xin guowen 共和國教科書 - 新國文 [Republic Textbook-New National Language], Gaodeng xiaoxuexiao vol. 2, (Shanghai: Shangwu yinshuguan, 1912), p. 21a.

${ }^{68}$ Cong, Teachers' Schools, pp. 95-103; Pepper, Radicalism and Educational Reform, pp. 61-2.
} 
the respiratory system and related ailments, explaining that foul air was the result of human breathing and that microbes in the air transmitted diseases from person to person. In a paragraph on 'Why air in rooms should be exchanged', the causes of and solutions to indoor air pollution were elucidated:

Air in rooms turns foul for a variety of reasons. For example, when people reside in rooms, oxygen will become depleted, while water damp and carbonic gases will accumulate... Therefore, it is imperative to emphasise the methods for air exchange, how to discharge foul indoor air, and introduce fresh air from the outdoors. ${ }^{69}$ The technicalities of efficient ventilation were further explained to these young students. Slightly vitiated air could be exchanged by natural ventilation through holes and slits in houses. However, in crowded rooms, or in rooms where indoor air was polluted by the waste gases of sick people or by tobacco smoke, doors and windows would have to be opened in order to obtain sufficient exchange of air. In public buildings with many people gathered, like factories, schools, theatres, and amusement facilities, it was necessary to install pipes, air vents, and fans, according to this textbook. To stay healthy, these primary school students were advised to sleep with their bedroom windows open. ${ }^{70}$

A new and more detailed curriculum was designed, and an elementary school law was passed in 1932. ${ }^{71}$ When new school textbooks were produced in China in 1933-1934 under these new regulations, hygiene was also introduced as a topic in the lower years of primary school. The importance of fresh air was explicated to students through simple illustrations on how to access sufficient amounts of fresh air while playing and studying, even though openair schools were never adopted in China. Perspectives on fresh and foul air were developed throughout the curriculum for primary school students and all the topics discussed in this paper on health, hygiene and air quality, air composition, waste-gases, dust, germs, and sunshine current in the scientific and public discourse in China in the middle of the 1930s were addressed and explained to these young students. They were advised how to ensure clean and fresh air, where to play, how to maintain a clean indoor environment, and interesting enough, even how to design houses and ventilate rooms in order to ensure a healthy indoor environment. The reward would be a happy childhood and effective learning. ${ }^{72}$

\footnotetext{
${ }^{69}$ Xin xuezhi weisheng jiaokeshu 新學制衛生教科書 [New Curriculum Hygiene Textbook], Xiaoxuexiao gaojiyong, vol. 2 (Shanghai: Shangwu yinshuguan, 1923-24), pp. 28-9.

${ }^{70}$ Ibid., pp. 29-30.

${ }^{71}$ Pepper, Radicalism and Educational Reform, pp. 37-45, 59-64.

${ }^{72}$ Fuxing weisheng jiaokeshu 復興衛生教科書 [Revival Hygiene Textbook], Chuxiao vol. 1-8, Gaoxiao vol. 14 (Shanghai: Shangwu yinshuguan, 1933-34); Xiaoxue weisheng keben 小學衛生課本, Chuji vol. 1-8, Gaoji vol. 1-4 (Shanghai: Zhonghua shuju, 1933-34); Weisheng keben 衛生課本, 1933-34, Chuji xiaoxue xueshengyong vol. 1-8, Gaoji xiaoxue xueshengyong vol. 1-4 (Shanghai: Shijie shuju).
} 
Modern architecture, access to sunlight, ${ }^{73}$ and public hygiene were evidently important aspects of the young state's endeavours to educate a band of young, modern citizens. Progressive knowledge of ventilation and hygiene was also directed at the new generation through edifying texts in children's magazines. The Children's Science Magazine published a series of articles on fresh air and ventilation in 1934 directed at children, unmistakeably aimed at forming educated, hygienically sound, and physically robust citizens for the Chinese nation. ${ }^{74}$ In a story published in the magazine Little Friend in 1934, the young Wei Jian (維建) represented an archetypical child of his time eager to learn about the modern principles of hygiene and ventilation at home. Wei Jian asked his father why their home was equipped with two holes in the wall when other houses were not. His father explained to him that those holes were air vents installed to move air. The son further inquired about the principles of air ventilation of homes, prompting his father's extensive explanation charged with technical details:

Simply relying on [open] windows is not sufficient because windows are all on one side [of the house], not enabling air to flow from one side to the other. That is why we have to install open air vents to enable exchange of air. Regarding the principles of air vents [situated] high and low, that is because indoor air is warm. When the air is warm, it expands and ascends, and hence is emitted through the upper vent. The outdoor air is cool. When the air is cool, it contracts and descends, and hence flows in through the lower vent. In that way, indoor air has one way in and one way out and will constantly be exchanged. ${ }^{75}$

\section{Conclusion}

The Western theories of hygiene introduced in China in the 1880s were targeted at the individual in order to replace traditional Chinese ways of 'preserving life' (weisheng) with modern scientific methods of ensuring a healthy life. With the influence of modern public hygiene theories and practices from the West via Japan after 1900, the Chinese discursive focus shifted from individual health to public hygiene. In the ensuing years, in particular after the establishment of the republic in 1912, hygienic modernity (weisheng) was diffused to the public through popular media, education, and many other platforms of government propaganda. It became one of the central elements in China's quest for a strong and healthy

\footnotetext{
${ }^{73}$ Fuxing weisheng jiaokeshu 復興衛生教科書 [Revival Hygiene Textbook], Chuxiao vol. 7 (Shanghai: Shangwu yinshuguan, 1933-34), pp. 14-5.

${ }^{74}$ Ertong kexue zazhi 兒童科學雜誌 [Children's Science Magazine], 1, no. 2 (1934): 7-11; 1, no. 5 (1934): 1318; 1, no. 8 (1934): 25-30.

75 'Xi xinxian kongqi’ 吸新鮮空氣 [Breathing Fresh Air], Xiao pengyou 小朋友 602 (1934): 2-3.
} 
nation: 'Weisheng resonated through advertisements, lecture halls, movie theatres, wall posters, newspapers, magazine articles, and government propaganda as a wide variety of actors used the word to help them imagine the condition of modernity'. ${ }^{76}$ Modern mass education on health and hygiene was the main means by which the republican government sought to foster and develop national subjects, as proclaimed by the Ministry of Education in November 1912:

Special attention should be paid to all matters relating to national morality, regardless of the specific course. Knowledge and skills should be taught in accord with the needs of life, and repeatedly practiced to the point they become automatic. It is hoped that students' bodies are developed in complete health, and teaching must be in accord with the stage of development of students' bodies and minds. ${ }^{77}$

This state-initiated movement to foster a strong nation through ways and means of hygienic modernity reached its peak during the New Life Movement in 1934: 'Launched in 1934 by Chiang Kai-shek and his wife Soong Mei-ling, the New Life Movement sought to revitalize the Chinese nation by reforming the bodily habits of the Chinese people' ${ }^{78}$ Fresh air became one of the prerequisites for this national desire for hygienic modernity, for public health, for fostering strong Chinese citizens, and for building a strong Chinese nation. The process commenced with the scientific introduction of knowledge about air into China in 1849 and terminated with the end of the republican government in China in 1949 (when the public discourse in the PRC took an entirely different direction), peaking in the 1920s and 30s. Foul air, dust, bacteria - and poorly ventilated rooms - were construed as the foes of modern life and a strong nation in China. Western miasmic theories dominated the early phase of the modern discourse, providing explanations for foul air, dust, and bacteria as health threatening wastes emitted from decaying matter and human breathing. In the mid-1920s, modern scientific theories and germ theory replaced miasmic theories, and in the 1930s and 40s the focus shifted to how modern architecture, modern life, and modern hygiene as science were to be employed to mitigate the effects of dust and bacteria and provide sufficient fresh air and sunlight to safeguard health and contribute to the building of a strong nation. An essential part of this national effort consisted of conveying this knowledge to the young generation of modern citizens through children's magazines and modern primary education. The series of articles on fresh air and ventilation in the Children's Scientific Magazine and the story about

\footnotetext{
${ }^{76}$ Rogaski, Hygienic Modernity, p. 226.

77 Zarrow, Educating China, p. 28. Similar perspectives on hygiene (weisheng) as a prerequisite for the new nation were expressed by the first president of the republic, Yuan Shikai, in January 1913. Xi Gao, 'Foreign Models of Medicine in Twentieth-Century China.' in Andrews and Bullock (eds.), Medical Transitions (Bloomington \& Indianapolis: Indiana University Press, 2014), pp. 173-4.

${ }^{78}$ Rogaski, Hygienic Modernity, p. 238. See also Andrews, The Making of Modern Chinese Medicine, pp. 94-6.
} 
Wei Jian in Little Friend in 1934 are typical examples of how this national quest for hygiene and strength, in the form of technical instructions for ventilation of homes, was conveyed to children. By introducing the hygienic necessity of air exchange and the technology for ventilation to the young generation through education and children's magazines, new China would purportedly succeed in fostering a strong nation of healthy citizens.

\section{ACKNOWLEDGEMENTS}

Research for this article as part of the 'Airborne' project was generously supported by the Research Council of Norway and the Centre for Advanced Study, Norway. Special thanks to the anonymous readers for their helpful suggestions for revision of the article. Many thanks also to colleagues in the 'Airborne' project for helpful feedback and suggestions on earlier drafts of this article. 